\title{
HUBUNGAN PENGETAHUAN DAN SUMBER INFORMASI DENGAN TINDAKAN PENCEGAHAN PENULARAN HIV/ AIDS PADA SISWA KELAS X SMA NEGERI PURWODADI KABUPATEN MUSI RAWAS
}

\section{The Relationship between Knowledge and Information Sources with Preventive Measures for the Transmission of HIV / AIDS in Class XI Students of Purwodadi State High School Musi Rawas District}

\author{
Dewi Aprilia Ningsih $\mathbf{I}^{1}$, Sanisahhuri ${ }^{2}$, Dewi Agustin ${ }^{1}$ \\ ${ }^{1}$ Program Studi DIV Kebidanan STIKES Tri Mandiri Sakti Bengkulu \\ ${ }^{2}$ Program Studi Kesehatan Masyarakat STIKES Tri Mandiri Sakti Bengkulu \\ Email: dewiaprilianingsih.i@gmail.com
}

\begin{abstract}
ABSTRAK
Pencegahan penularan HIV AIDS merupakan segala upaya dan kegiatan yang dilakukan meliputi kegiatan pencegahan, penanganan, dan rehabilitasi. Penelitian ini dilakukan untuk mempelajari hubungan pengetahuan dan sumber informasi dengan tindakan pencegahan penularan HIV/AIDS pada siswa kelas XI SMA Negeri Purwodadi Kabupaten Musi Rawas. Penelitian telah dilakukan di SMA Negeri Purwodadi Kabupaten Musi Rawas pada tanggal 25 - 31 Juli tahun 2018. Jenis penelitian ini bersifat Survey Analitik dengan desain Cross Sectional. Populasi penelitian ini adalah seluruh siswa SMA Negeri Purwodadi Kabupaten Musi Rawas. Pengambilan sampel dilakukan dengan menggunakan Proportional Stratified Random Sampling yaitu sebanyak 68 responden. Pengumpulan data dalam penelitian ini menggunakan kuesioner dan wawancara. Teknik analisis data dilakukan dengan analisis univariat dan bivariat dengan uji Chi-Square $\left(\chi^{2}\right)$ melalui program SPSS, untuk mengetahui keeratan hubungan dengan menggunakan Contingency Coefficient (C). Hasil penelitian: dari 68 siswa SMA terdapat 46 siswa $(67,6 \%)$ yang memiliki pengetahuan baik, 45 siswa $(66,2 \%)$ yang memiliki banyak sumber informasi, 59 siswa (86,8\%) yang melakukan tindakan pencegahan. Ada hubungan yang signifikan antara pengetahuan dengan tindakan pencegahan penularan HIV/AIDS pada siswa kelas XI SMA Negeri Purwodadi tahun 2018 dengan kategori hubungan sedang, ada hubungan yang signifikan antara sumber informasi dengan tindakan pencegahan penularan HIV/AIDS pada siswa kelas XI SMA Negeri Purwodadi tahun 2018 dengan kategori hubungan lemah. Diharapkan bagi guru dan guru BP agar dapat meningkatkan pengetahuan siswa tentang tindakan pencegahan penularan HIV/AIDS.
\end{abstract}

Kata Kunci: pengetahuan, sumber informasi, tindakan pencegahan

\footnotetext{
ABSTRACT

Prevention of transmission of HIV AIDS is all the efforts and activities carried out include prevention, handling and rehabilitation activities. This research was conducted to study the relationship of knowledge and information sources with
} 
the prevention of HIV/ AIDS in class XI students of Purwodadi State High School, Musi Rawas Regency. Research had been carried out at Purwodadi State High School Musi Rawas Regency on July 25 to 31 2018. This research is an analytical survey with a cross sectional approach. The population of this study were all students of Purwodadi State High School, Musi Rawas Regency. Sampling was carried out using proportional stratified random sampling in the amount of 68 respondents. Data collection in this study uses questionnaires and interviews. Data analysis techniques were carried out by univariate and bivariate analysis using Chi-Square test $\left(\chi^{2}\right)$ through the SPSS program, to determine the closeness of the relationship using Contingency Coefficient $(C)$. The results of the study: from 68 students from Purwodadi State High School in Musi Rawas Regency there were 46 students (67.6\%) who had good knowledge, 45 students (66.2\%) who had many sources of information, 59 students $(86.8 \%)$ who did precautionary action, there is a significant relationship between knowledge with the prevention of HIV / AIDS in class XI of Purwodadi State High School in 2018 with the moderate relationship category, there is a significant relationship between information sources and prevention of HIV/ AIDS transmission in class XI Purwodadi State High School in 2018 with a weak relationship category. It is expected that teachers can improve students knowledge about the prevention of HIV/ AIDS.

Keywords: knowledge, information sources, preventive measures

\section{A. Pendahuluan}

Laporan akhir tahun 2006, UNAIDS (United Nations Programme On HIV/AIDS)/ WHO (World Health Organization) mengemukakan bahwa terdapat sekitar 39,5 juta orang di seluruh dunia dan hidup dengan HIV positif. Organisasi ini telah menetapkan tujuan ambisius yaitu zero new HIV infection dan zero AIDS related deaths yang dicanangkan akan tercapai pada 2015. (Feilan, 2012 dalam Manafe, Kandao, \& Posangi, 2014)

Pada tahun 2013 di seluruh dunia ada 35 juta orang hidup dengan HIV yang meliputi 16 juta perempuan dan 3,2 juta anak berusia $<15$ tahun. Jumlah infeksi baru HIV pada tahun 2013 sebesar 2,1 juta yang terdiri dari 1,9 juta dewasa dan 240.000 anak berusia <15 tahun. Jumlah kematian akibat AIDS sebanyak 1,5 juta yang terdiri dari 1,3 juta dewasa dan 190.000 anak berusia $<15$ tahun (Pusat Data dan Informasi Kemenkes RI, 2014).
Human Immunodeficiency Virus (HIV) virus yang menyerang sistem kekebalan tubuh manusia dan dapat menimbulkan AIDS. HIV menyerang salah satu jenis dari sel-sel darah putih yang bertugas menangkal infeksi. Sel darah putih tersebut terutama limfosit yang memiliki CD4 sebagai sebuah marker atau penanda yang berada dipermukaan sel limfosit (Walyani, 2015).

Acquired Immune Deficiency Syndrome (AIDS) adalah sekumpulan gejala (sindrom) dari berbagai penyakit yang disebabkan oleh virus HIV (Human Immunodeficiency Virus) yang dapat menghancurkan system kekebalan tubuh dan dapat menyebabkan terjadinya infeksi dan kanker fatal. Biasanya sistem kekebalan tubuh melindungi tubuh terhadap penyakit, akantetapi kalau sistem kekebalan tubuh dirusak oleh virus AIDS, maka serangan penyakit yang biasanya tidak berbahaya akan 
menjadi sangat berbahaya karena tubuh orang tersebut tidak bisa lagi memeranginya, yang pada akhirnya akan menyebabkan kematian karena infeksi tersebut (Maryunani, 2013).

Remaja adalah masa transisi sebagai proses dalam mempersiapkan diri meninggalkan dunia anak-anak untuk memasuki dunia orang dewasa pada masa ini terjadi banyak perubahan pada diri remaja yang meliputi berbagai dimensi yaitu dimensi fisik, kognitif, psikologis, dan dimensi moral atau sosial. Sayangnya banyak remaja yang belum siap atau belum dipersiapkan untuk menghadapi masa transisi ini sehingga yang seringkali terjadi pada remaja adalah perubahan ataukematangan secara fisik saja tanpa diimbangi dengan kematangan secara psikologis dan kognitif (Mahfiana, 2011).

Ada beberapa faktor yang mendorong anak remaja usia SMP dan SMA melakukan perilaku menyimpang seperti hubungan seks di luar nikah. Faktor-faktor tersebut diantaranya pengaruh liberalisme atau pergaulan hidup bebas, faktor lingkungan dan keluarga yang mendukung kearah prilaku tersebut serta pengaruh perkembangan media masa dan ketidaktahuan siswa terhadap bahaya dan cara pencegahan penularan HIV/AIDS. Oleh karena itu, dengan adanya perilaku seperti itu, para remaja tersebut sangat rentan terhadap resiko kesehatan seperti penularan HIV/AIDS, penggunaan narkoba serta penyakit lainnya (Noviana, 2013).

Pencegahan penularan HIV AIDS merupakan segala upaya dan kegiatan yang dilakukan meliputi kegiatan pencegahan, penanganan, dan rehabilitasi. Seperti diketahui penyebaran virus HIV melalui hubungan seks, jarum suntik yang tercemar, transfusi darah, penularan dari ibu ke anak maupun donor darah atau donor organ tubuh. Cara pencegahan penularan HIV yang paling efektif adalah dengan memutus rantai penularan (Noviana, 2013).

Masih banyak remaja yang belum mengetahui tentang pencegahan penularan HIV/AIDS. Menurut Sigit et al (2015), penularan HIV terjadi karena kurangnya pengetahuan di kalangan remaja tentang penularan HIV/AIDS. Remaja harus paham pentingnya kesehatan reproduksi dengan menghindari seks bebas untuk mencegah penularan. Selain itu, remaja sering salah mempersepsikan tentang informasi mengenai seks dari teman sebaya, film atau buku yang isinyajauh menyimpang dari nilai-nilai etika dan moral, yang pada akhirnya dapat menyebabkan remaja terjerumus ke persoalan seksualitas yang kompleks termasuk resiko penularan HIV/AIDS (Sigit et al, 2015).

Berdasarkan data terakhir dari Dinas Kesehatan Provinsi Sumatera jumlah penderita HIV di Sumatra Selatan dari tahun 2009-2016 berjumlah 2.128 orang. Dan pada tahun 2016 penderita HIV berjumlah 150 orang. Sedangkan Penderita AIDS dari tahun 2009-2016 berjumlah 691 orang. Dan pada tahun 2016 berjumlah 107 orang (Dinkes Provinsi Sumatera Selatan, 2016).

Jumlah orang yang di test HIV/AIDS Kabupaten MusiRawas pada tahun 2017 berjumlah 404 orang, jumlah orang yang HIV/AIDS positif laki-laki berjumlah 12 0rang, perempuan 8 orang dan kelompok resiko berjumlah 20 orang. Maka dilakukan sosialisasi di kalangan pelajar agar dapat melakukan pencegahan (Dinkes Kabupaten Musi Rawas, 2017).

Berdasarkan data dari SMA Negeri Purwodadi diperoleh data 
jumlah keseluruhan siswa berjumlah 641 siswa. Terdiri dari 234 siswa lakilaki dan 398 siswa perempuan (SMA Negeri Purwodadi, 2018).

Rumusan masalah dalam penelitian ini adalah apakah terdapat hubungan antara pengetahuandan sumber informasi dengan tindakan pencegahan penularan HIV/AIDS pada siswa kelas XI SMA N Purwodadi Kabupaten Musi Rawas?. Tujuan penelitin ini adalah untuk mengetahui apakah terdapat hubungan antara pengetahuandan sumber informasi dengan tindakan pencegahan penularan HIV/AIDS pada siswa kelas XI SMA N Purwodadi Kabupaten Musi Rawas.

\section{B. Metode Penelitian}

Penelitian dilakukan di SMA Negeri Purwodadi Kabupaten Musi Rawas pada tanggal 25-31 Juli tahun 2018. Jenis penelitian ini bersifat Survey Analitik dengan pendekatan Cross Sectional. Populasi penelitian ini adalah seluruh siswa SMA Negeri Purwodadi Kabupaten MusiRawas. Pengambilan sampel dilakukan dengan menggunakan Proportional Stratified Random Sampling yaitu sebanyak 68 siswa. Pengumpulan data dalam penelitian ini menggunakan kuesioner dan wawancara. Teknik analisis data dilakukan dengan analisis univariat dan bivariate dengan uji Chi-Square $\left(\chi^{2}\right)$ melalui program SPSS, untuk mengetahui keeratan hubungan dengan menggunakan Contingency Coefficient (C).

\section{Hasil Penelitian}

\section{Analisis Univariat}

Analisis univariat dilakukan untuk melihat distribusi frekuensi variabel independent (pengetahuan dan sumber informasi) dan variabel dependent (pencegahan penularan HIV/ AIDS).

Tabel 1

Distribusi Frekuensi Tindakan Pencegahan Penularan HIV/AIDS pada Siswa Kelas XI SMA Negeri Purwodadi Kabupaten Musi Rawas

\begin{tabular}{ccc}
\hline \multicolumn{1}{c}{ Tindakan Pencegahan } & Jumlah & Persentase (\%) \\
\hline Tidak Mencegah & 9 & 13,2 \\
Mencegah & 59 & 86,8 \\
\hline \multicolumn{1}{c}{ Jumlah } & 68 & 100,0 \\
\hline
\end{tabular}

Berdasarkan Tabel 1 dapat penularan HIV/AIDS dan responden diketahui bahwa dari 68 siswa terdapat yang melakukan tindakan pencegahan 9 siswa (13,2\%) tidak mencegah penularan HIV/AIDS 59 siswa $(86,8 \%)$

Tabel 2

Distribusi Frekuensi Pengetahuan pada Siswa Kelas XI SMA Negeri Purwodadi Kabupaten Musi Rawas

\begin{tabular}{lcc}
\hline \multicolumn{1}{c}{ Pengetahuan } & Jumlah & Persentase (\%) \\
\hline Kurang & 4 & 5,9 \\
Cukup & 18 & 26,5 \\
Baik & 46 & 67,6 \\
\hline Jumlah & 68 & 100,0 \\
\hline
\end{tabular}


Berdasarkan Tabel 2 dapat kurang, 18 siswa (26,5\%) pengetahuan diketahui bahwa dari 68 siswa terdapat cukup dan 46 siswa $(67,6 \%)$ 4 siswa $(5,9 \%)$ dengan pengetahuan pengetahuan baik.

Tabel 3

Distribusi Frekuensi Sumber Informasi pada Siswa Kelas XI SMA Negeri Purwodadi Kabupaten Musi Rawas

\begin{tabular}{lcc}
\hline \multicolumn{1}{c}{ Sumber Informasi } & Frekuensi & Persentase (\%) \\
\hline Sedikit & 23 & 33,8 \\
Banyak & 45 & 66,2 \\
\hline Total & 68 & 100,0 \\
\hline
\end{tabular}

Berdasarkan Tabel 3 dapat diketahui bahwa dari 68 siswa terdapat 23 siswa $(33,8 \%)$ dengan informasi sedikit dan 45 siswa $(66,2 \%)$ dengan sumber informasi banyak.

\section{Hasil Analisis Bivariat}

Analisis bivariat dilakukan untuk melihat distribusi frekuensi variabel independent (pengetahuan dan sumber informasi) dan variabel dependent (pencegahan penularan HIV/ AIDS). Uji hubungan dilakukan dengan uji statistik Chi-Square sedangkan uji keeratan hubungan dilakukan dengan uji statistik koefisien kontingensi.

Tabel 4

Hubungan Pengetahuan dengan Tindakan Pencegahan Penularan HIV/AIDS pada Siswa Kelas XI SMA Negeri Purwodadi Kabupaten Musi Rawas

\begin{tabular}{|c|c|c|c|c|c|c|c|c|c|}
\hline \multirow{3}{*}{ Pengetahuan } & \multicolumn{6}{|c|}{$\begin{array}{c}\text { Tindakan Pencegahan Penularan } \\
\text { HIV/AIDS }\end{array}$} & \multirow{3}{*}{$\chi^{2}$} & \multirow{3}{*}{$p$} & \multirow{3}{*}{$C$} \\
\hline & \multicolumn{2}{|c|}{$\begin{array}{c}\text { Tidak } \\
\text { Mencegah }\end{array}$} & \multicolumn{2}{|c|}{ Mencegah } & \multicolumn{2}{|c|}{ Total } & & & \\
\hline & $\mathrm{F}$ & $\%$ & $\mathrm{~F}$ & $\%$ & $\mathrm{~F}$ & $\%$ & & & \\
\hline Kurang & 3 & 75,0 & 1 & 25,0 & 4 & 100,0 & & & \\
\hline Cukup & 3 & 16,7 & 15 & 83,0 & 18 & 100,0 & 15278 & 0000 & 0 \\
\hline Baik & 3 & 6,5 & 43 & 93,5 & 46 & 100,0 & ס & 0,000 & $0,4 \angle 0$ \\
\hline Total & 9 & 13,2 & 59 & 86,8 & 68 & 100,0 & & & \\
\hline
\end{tabular}

Pada Tabel 4, dapat dilihat bahwa dari 4 orang pengetahuan kurang terdapat 3orang tidak mencegah dan 1 orang mencegah, dari 18 orang pengetahuan cukup terdapat 3 orang mencegah dan 15 orang tidak mencegah dan dari 46 orang pengetahuan baik terdapat 3 orang tidak mencegah dan 43 orang mencegah.
Hasil uji Contingency Coefficient didapat nilai $\mathrm{C}=0,428$ dengan $\mathrm{P}=0,000<0,05$ berarti signifikan. Nilai $\mathrm{C}=0,570$ tersebut dibandingkan dengan nilai $C_{\max }=\sqrt{\frac{m-1}{m}}=\sqrt{\frac{2-1}{2}}=\sqrt{\frac{1}{2}}=$ 0,707 (karena nilai terendah dari baris atau kolom adalah 2). Karena nilai $\mathrm{C}_{\max }$ 
tidak jauh dengan nilai $\mathrm{C}_{\max }=0,707$ maka kategori hubungan sedang.

Tabel 5

Hubungan Sumber Informasi dengan Tindakan Pencegahan Penularan HIV/AIDS pada Siswa Kelas XI SMA Negeri Purwodadi Kabupaten Musi Rawas

\begin{tabular}{|c|c|c|c|c|c|c|c|c|}
\hline \multirow{3}{*}{$\begin{array}{l}\text { Sumber } \\
\text { Informasi }\end{array}$} & \multicolumn{6}{|c|}{ Tindakan Pencegahan Penularan HIV/AIDS } & \multirow{3}{*}{$p$} & \multirow{3}{*}{$C$} \\
\hline & \multicolumn{2}{|c|}{ Tidak Mencegah } & \multicolumn{2}{|c|}{ Mencegah } & \multicolumn{2}{|c|}{ Total } & & \\
\hline & $\mathrm{F}$ & $\%$ & $\mathrm{~F}$ & $\%$ & $\mathrm{~F}$ & $\%$ & & \\
\hline Sedikit & 7 & 30,4 & 16 & 69,6 & 23 & 100,0 & & \\
\hline Banyak & 2 & 4,4 & 43 & 95,6 & 45 & 100,0 & 0,005 & 0,341 \\
\hline Total & 9 & 13,2 & 59 & 86,8 & 68 & 100,0 & & \\
\hline
\end{tabular}

Pada Tabel 5, dapat dilihat bahwa dari ternyata dari 23 orang sumber informasi sedikit terdapat 7 orang tidak mencegah dan 16 orang mencegah dan dari 45 orang sumber informasi banyak terdapat 2 orang mencegah dan 43 orang tidak mencegah.

Hasil uji Fisher's Exact Test didapat nilai dengan $\mathrm{p}=0,005<0,05$ berarti signifikan, maka Ho ditolak Ha diterima. Jadi terdapat hubungan yang signifikan antara sumber informasi dengan tindakan pencegahan penularan HIV/AIDS.

Hasil uji Contingency Coefficient didapat nilai $\mathrm{C}=0,341$ dengan $\mathrm{P}=0,005<0,05$ berarti signifikan. Nilai $\mathrm{C}=$.341tersebut dibandingkan dengan nilai $\mathrm{C}_{\max }=\sqrt{\frac{\mathrm{m}-1}{\mathrm{~m}}}=\sqrt{\frac{2-1}{2}}=\sqrt{\frac{1}{2}}=$ 0,707 (karena nilai terendah dari baris atau kolom adalah 2). Karena nilai $\mathrm{C}_{\max }$ jauh dengan nilai $\mathrm{C}_{\max }=0,707$ maka kategori hubungan lemah.

\section{Pembahasan}

Berdasarkan Tabel 1 yang dilakukan penelitian di SMA Negeri Purwodadi Kabupaten Musi Rawas dari 68 siswa terdapat 9 responden $(13,2 \%)$ yang tidak mencegah HIV/AIDS. Hal ini dikarenakan siswa tidak mengetahui pengertian HIV dan bahaya HIV/AID, sebagian juga banyak tidak mengetahui penyebab dari HIV/AIDS dan bagaimana cara penularan serta dampak yang akan terjadi akibat dari HIV/AIDS, sehingga siswa ini menganggap bahwa HIV/AIDS ini suatu hal yang biasa saja.

Dari 59 siswa $\quad(86,8 \%)$ melakukan tindakan pencegahan penularan HIV/AIDS. Hal ini dikarenakan siswa mengetahui pengertian dan bahaya HIV/AIDS, sebagian siswa juga banyak mengetahui penyebab dari HIV/AIDS dan bagaimana cara penularan HIV/AIDS itu sendiri, sehingga para siswa mengantisipasi dengan melakukan pencegahan terhadap HIV/AIDS.

Berdasarkan Tabel 2 dapat diketahui bahwa dari 68 siswa, terdapat 46 siswa $(67,65 \%)$ yang memiliki pengetahuan baik, hal ini dikarenakan siswa sudah mengetahui pengertian HIV/AIDS, bagaimana pencegahan HIV/AIDS dan bagaimana cara penularan HIV/AIDS. 18 responden $(26,5 \%)$ yang memiliki pengetahuan cukup, dan 4 siswa $(5,9 \%)$ yang memiliki pengetahuan kurang, hal ini dikarenakan siswa tidak mengetahui pengertian HIV/AIDS, bagaimana pencegahan HIV/AIDS dan bagaimana cara penularan HIV/AIDS. Berarti sebagian besar siswa SMA Negeri 
Purwodadi mempunyai pengetahuan yang baik tentang HIV/AIDS.

Berdasarkan Tabel 3 diketahui bahwa dari 68 siswa yang banyak informasi 45 siswa $(66,2 \%)$, hal ini dikarenakan siswa banyak memperoleh sumber informasi tentang HIV/AIDS dari media masa, keluarga, tenaga kesehatan,guru serta teman sebaya. Tentang pengertian, bagaimana pencegahan HIV/AIDS dan bagaimana cara penularan HIV/AIDS.

Sedikit informasi 23 siswa $(33,8 \%)$, hal ini dikarenakan siswa kurang memperoleh informasi, tentang pengertian, bagaimana pencegahan HIV/AIDS dan bagaimana cara penularan HIV/AIDS.

Berdasarkan Tabel 4 diketahui bahwa dari 68 siswa. 4 siswa pengetahuan kurang terdapat 3 siswa tidak mencegah, hal ini dikarenakan siswa kurang mendapatkan informasi, pendidikan, serta penyuluhan tentang HIV/AIDS. Dan karena faktor lingkungan yang kurang baik serta pergaulan yang terlalu bebas serta kurang mendapatkan kasih sayang dan perhatian dari kedua orang tuanya sehingga mereka tidak melakukan tindakan pencegahan..1 siswa mencegah, walaupun pengetahuannya kurang tetapi siswa tersebut mencegah dikarenakan tingkat keagamaannya yang baik, faktor lingkungan yang baik, didikan dari keluarganya yang baik, faktor lingkungan yang baik serta teman sebaya yang baik. Dan siswa tersebut takut melakukan seks bebas karena takut hamil sehingga siswa tersebut melakukan tindakan pencegahan HIV/AIDS.

Dari 18 siswa pengetahuan cukup terdapat 3 siswa tidak mencegah, dikarenakan faktor lingkungan dan teman sebaya yang kurang baik, faktor kebebasan dari kedua orang tua, dan karena pergaulan yang terlalu bebaa sehingga siswa tersebut tidak mencegah. 15 siswa mencegah. Hal ini dikarenakan didikan dari orang tua dan keluarga, siswa juga sering mencari tahu informasi tentang HIV di media sosial. Dan siswa tersebut takut sama orang tua sehingga mereka harus menjaga diri agar tidak terkena HIV/AIDS.

Dari 46 siswa pengetahuan baik terdapat 3 siswa tidak mencegah, dikarenakan faktor lingkungan, didikan orang tua dan keluarga, pergaulan bebas, kurang perhatian dan kasih sayang dari keluarga. Dan 43 siswa mencegah, hal ini dikarenakan siswa sudah pernah mengikuti penyuluhan tentang HIV/AIDS, didikan dari orang dan keluarganya yang baik, perilaku siswa yang baik, serta siswa tersebut banyak mendapatkan sumber informasi tentang HIV/AIDS sehingga siswa tersebut melakukan tindakan pencegahan. Hasil uji Pearson ChiSquare didapat nilai $\mathrm{p}=0,000<0,05$ artinya ada hubungan yang signifikan antara pengetahuan dengan tindakan pencegahan penularan HIV/AIDS pada siswa kelas XI SMA Negeri Purwodadi Kabupaten Musi Rawas. Hasil uji Contingency Coefficient didapat kategori hubungan sedang.

Hasil penelitian ini sejalan dengan yang dilakukan oleh Juliastika, Korompis, \& Ratag (2012), yang menyatakan bahwa ada hubungan antara pengetahuan tentang HIV/AIDS dengan tindakan penggunaan kondom pria pada wanita pekerja seks di Kota Manado. Sesuai pendapat Notoatmodjo (2012) bahwa pengetahuan terdiri dari enam tingkatan yaitu tahu, memahami, aplikasi, sintesis, analisis dan evaluasi. Mengacu pada siswa SMA Negeri Purwodadi Kabupaten Musi Rawas, sebagian besar sudah sampai pada tahap bisa mengevaluasi pengetahuan tentang HIV/AIDS. 
Dari 23 orang sumber informasi sedikit terdapat 7 siswa tidak mencegah, siswa dikarenakan siswa tersebut malas mencari sumber informasi tentang HIV/AIDS serta rasa keingintahuan siswa itu kurang. Dan 16 siswa mencegah, hal ini dikarenakan pergaulan yang baik dengan lingkungan dan teman sebaya, faktor didikan orang tua yang baik, sikap dan prilaku siswa yang bagus, siswa pintar menjaga diri sehingga siswa melakukan pencegahan.

Dari 45 siswa sumber informasi banyak terdapat 2 siswa tidak mencegah, hal ini dikarenakan pergaulan siswa yang terlalu bebas, pengaruh dari teman sebaya, kurang kasih sayang dan perhatian dari orang tua, siswa tersebut kurang menjaga diri sehingga tidak melakukan tindakan pencegahan HIV/AIDS. Dan 43 siswa melakukan pencegahan, hal ini dikarenakan siswa memiliki banyak sumber informasi dari orang tua, tenaga kesehatan dan media sosial tentang HIV/AIDS, faktor lingkungan yang baik, serta siswa tersebut pernah mengikuti penyuluhan tentang bahaya seks bebas, sehingga siswa tersebut melakukan tindakan pencegahan.

Hasil uji Fisher's Exact Test didapat nilai dengan $\mathrm{p}=0,005<0,05$ berarti signifikan, Jadi terdapat hubungan yang signifikan antara sumber informasi dengan tindakan pencegahan penularan HIV/AIDS pada siswa kelas XI SMA Negeri Purwodadi Kabupaten Musi Rawas. Hasil uji contingency coefficient didapat kategori hubungan lemah.

Hasil penelitian sejalan dengan yang didapatkan peneliti Noorhidayah, Al Banjary, \& Asrinawaty. (2016) bahwa ada hubungan sumber informasi dengan tindakan penularan HIV/AIDS pada siswa SMA Negeri Purwodadi Kabupaten Musi Rawas. Secara umum semua sumber informasi adalah suatu sumber pengetahuan dan belajar, karena dalam sumber informasi selalu terkandung hal-hal yang dapat digunakan sebagai sumber belajar, hanya saja itu semua tergantung pada kebutuhan belajar masing-masing individu dalam memanfaatkan sumber informasi

\section{E. Kesimpulan}

1. Dari 68 siswa terdapat 59 siswa $(86,8 \%)$ yang melakukan tindakan pencegahan penularan HIV/AIDS.

2. Dari 68 siswa terdapat 46 siswa $(67,6 \%)$ yang memiliki pengetahuan baik.

3. Dari 68 siswa terdapat 45 siswa $(66,2 \%)$ yang banyak sumber informasi.

4. Ada hubungan yang signifikan antara pengetahuan dengan tindakan pencegahan penularan HIV/AIDS pada siswa kelas XI SMA Negeri Purwodadi Kabupaten Musi Rawas dengan kategori hubungan sedang

5. Ada hubungan yang signifikan antara sumber informasi dengan tindakan pencegahan penularan HIV/AIDS pada siswa kelas XI SMA Negeri Purwodadi Kabupaten MusiRawas dengan kategori hubungan lemah.

\section{Daftar Pustaka}

Dinkes Kabupaten Musi Rawas. (2017). Data HIV/AIDS Kabupaten Musi Rawas. Musi Rawas: Dinkes Kabupaten Musi Rawas.

Dinkes Provinsi Sumatera Selatan. (2016). Data HIV/AIDS Provinsi Sumatera Selatan. Sumatera Selatan: Dinkes Provinsi Sumatera Selatan.

Dinkes Provinsi Sumatera Selatan. (2016). Profil Kesehatan Provinsi Sumatra Selatan. 
Palembang: Dinkes Provinsi Sumatera Selatan.

Ditjen PP\&PL Kemenkes RI. (2014). Situasi dan Analisis HIV AIDS. Jakarta: Ditjen PP\&PL Kemenkes RI .

Juliastika, Korompis, G. E. C, \& Ratag, B. T. (2012). Hubungan Pengetahuan Tentang HIV/AIDS dengan Sikap Tindakan Penggunaan Kondom Pria pada Wanita di Kota Manado. Kesmas, 1 (1), 15-20. Diunduh dari: https://ejournal.unsrat.ac.id/inde x.php/kesmas/article/view/79/7 5.

Mahfiana. (2011). Remaja dan Kesehatan Reproduksi. Yogyakarta: STAIN Ponorogo Press

Manafe, L. A., Kandou, G. D., \& Posangi, J. (2014). Hubungan antara Pengetahuan, Sikap, Peran Guru, Media Informasi (Internet) dan Peran Teman Sebaya dengan Tindakan Pencegahan HIV/AIDS pada Siswa di SMA Negeri 4 Manado. JIKMU, 4 (4), 644655. Diunduh dari: https://ejournal.unsrat.ac.id/inde x.php/jikmu/article/view/7685/7 251.

Maryunani, A. (2013). Pencegahan penularan HIV dari Ibu ke Bayi: Penatalaksanaan di Pelayanan Kebidanan. Jakarta: CV. Trans Info Media
Noorhidayah, Al Banjary, M. A., \& Asrinawaty. (2016). Hubungan Pengetahuan, Sikap, dan Sumber Informasi dengan Upaya Pencegahan HIV/AIDS pada Remaja Komunitas Anak Jalanan di Banjarmasin tahun 2016. Dinamika Kesehatan. Jurnal Kebidanan dan Keperawatan, 7 (1). Diunduh dari:

http://ojs.dinamikakesehatan.sti kessarimulia.ac.id/index.php/dk sm/article/view/83/63.

Notoatmodjo, S. (2012). Metodologi Penelitian Kesehatan. Jakarta: Rineka Cipta.

Noviana, N. (2013). Catatan Kuliah Kesehatan Reproduksi \& HIV/AIDS. Jakarta: CV. Trans Info Media

Pusat Data dan Informasi Kementerian Kesehatan RI. (2014). Situasi dan Analisis HIV AIDS. Jakarta: Kementerian Kesehatan Republik Indonesia

Sigit, et al. (.2015). HIV/AIDS. Jakarta: Gramedia.

SMA Negeri Purwodadi. (2018). Data siswa-siswi SMA Negeri Purwodadi Kabupaten Musi Rawas Tahun 2018. Purwodadi: SMA Negeri Purwodadi.

Walyani, E. S. (2015). Epidemiologi Penyakit Menular \& Tidak Menular. Jakarta: CV. Trans Info Media. 